Berkala Ilmu Perpustakaan dan Informasi, Vol. 16, No. 1, Juni 2020, Hal. 111-126 DOI: 10.22146/bip.v16i1.94

ISSN 1693-7740 (Print), ISSN 2477-0361 (Online)

Tersedia online di https://journal.ugm.ac.id/v3/BIP

\title{
Evaluasi budaya organisasi Perpustakaan Nasional Republik Indonesia
}

\author{
Salahudin $^{1}$, Achmad Nurmandi ${ }^{2}$, Joko Santoso ${ }^{3}$, Budi Kusumawardhani ${ }^{3}$, Rusdianto ${ }^{4}$, Rendra \\ Agusta $^{5}$, Mohammad Jafar Loilatu ${ }^{2}$ \\ ${ }^{1}$ Prodi Ilmu Pemerintahan, Universitas Muhammadiyah Malang \\ ${ }^{2}$ Jusuf Kalla School of Government, Universitas Muhammadiyah Yogyakarta \\ ${ }^{3}$ Perpustakaan Nasional Republik Indonesia, ${ }^{4}$ Universitas Harapan Nasional Surabaya \\ ${ }^{5}$ Konsultan Sinergi Visi Utama Yoyakarta \\ ${ }^{1}$ Jl. Raya Tlogomas No.246 Malang, Jawa Timur 6544 \\ e-mail: salahudinmsi@umm.ac.id
}

Naskah diterima: 21 Februari 2020, direvisi: 7 April 2020, disetujui: 8 Mei 2020

\begin{abstract}
ABSTRAK
Pendahuluan. Penelitian ini dilakukan untuk mengetahui budaya organisasi pada aspek clan (manajemen SDM), adhocracy (inovasi organisasi), market (adaptasi dan strategis organisasi), dan hierarchy (koordinasi dan struktur organisasi).

Metode penelitian. Penelitian ini menggunakan pendekatan Competing Values Framework (CVF) yang dikembangkan oleh Cameron \& Quinn (2011) di mana pendekatan ini merupakan bagian dari jenis penelitian kuantitatif karena pendekatan dan instrumen ini menggunakan kuesioner untuk mendapatkan data score dan ratarata dari masing-masing aspek budaya organisasi.

Analisis Data. Organizational Culture Assessment Instrument (OCAI) adalah instrumen penilaian budaya organisasi dengan menggunakan pernyataan/pertanyaan yang berhubungan dengan enam subsistem budaya organisasi yaitu karakter dominan organisasi, gaya kepemimpinan, manajemen sumber daya manusia, solidaritas internal, manajemen strategis, dan kriteria sukses organisasi. Analisis data menggunakan SPSS dengan formula Pearson Correlation.

Hasil dan Pembahasan. Analisis profil budaya organisasi Perpustakaan Nasional mengungkapkan bahwa budaya organisasi Perpustakaan Nasional adalah dominan budaya hirarki.

Kesimpulan dan Saran. Budaya organisasi Perpustkaan Nasional Republik Indonesia (Perpusnas RI) saat ini (sekarang) menggambarkan budaya hirarki. Sejalan dengan nilai budaya organisasi saat ini, Perpusnas RI juga menghendaki budaya hirarki tetap dipertahankan sebagai bagian dari prinsip kerja organisasi. Budaya hirarki organisasi Perpusnas RI perlu didukung oleh kepemimpinan, manajemen, dan loyalitas, kepedualian, serta komitmen pimpinan dan pegawai Perpusnas RI.
\end{abstract}

Kata kunci: budaya organisasi; perpustakaan nasional; manajemen; inovasi; kepemimpinan

\section{ABSTRACT}

Introduction. This study aims to determine the organizational culture in the National Library of Indonesia (NLI) based on several aspects including clan (human resource management), adhocracy (innovation organization), market (adaptation and strategic organization), and hierarchy (coordination and organizational structure).

Research Methods. This study used a quantitative approach of Competing Values Framework (CVF) developed by Cameron \& Quinn (2011) to obtain data scores and the average of each aspect of organizational culture. 
Data Analysis. Organizational Culture Assessment Instrument (OCAI) is an organizational culture assessment instrument by using statements/questions relating to the six subsystems, namely organizational culture dominant characters, leadership, human resource management, internal solidarity, strategic management and organizational success criteria. The data was analysed by using SPSS with Pearson Correlation formula.

Results and Discussion. We found that organizational culture of the National Library is cultural hierarchy.

Conclusion and Recommendations. Organization culture of the (NLI) shows the cultural hierarchy. The cultural hierarchy is maintained as part of the working principles of the organization.

Keywords: Organizational culture; National library; Management; Innovation; Leadership.

\section{A. PENDAHULUAN}

Pengelola organisasi publik perlu melakukan kajian budaya organisasi untuk mengenal dan memahami kondisi internal dan eksternal organisasi. Dengan demikian, mereka dapat mendesain tata kelola organisasi yang dapat mendukung tercapainya visi, misi, dan tujuan organisasi secara efektif (Luhman and Cunliffe, 2014). Selain itu, pemimpin organisasi dapat mengidentifikasi tipe budaya organisasi secara jelas. Hasil dari kajian budaya organisasi dapat dijadikan sebagai dasar pengambilan keputusan yang dapat mendukung terbentuknya organisasi yang sehat (Pateman \& Pateman, 2017). Karena itu, pemerintah Indonesia melalui Kementerian Pendayagunaan Aparatur Negara dan Reformasi Birokrasi mengeluarkan Peraturan No. 19/2018 tentang Penyusunan Peta Proses Bisnis Instansi Pemerintah dan Peraturan No. 20/2018 tentang Pedoman Evaluasi Kelembagaan Instansi Pemerintah. Kedua peraturan tersebut menegaskan semua lembaga publik wajib melakukan evaluasi kelembagaan secara periodik.

Sebagai bagian dari organisasi pemerintah, Perpustakaan Nasional Republik Indonesia telah melakukan audit kelembagaan pada 2018 lalu (gambar 1). Audit kelembagaan Perpusnas dilakukan untuk mengukur kemampuan organisasi Perpusnas pada dimensi proses dan dimensi organisasi. Berdasarkan hasil audit, memiliki dukungan formalisasi, di mana terdapat sejumlah peraturan yang mendukung tata kelola perpustakaan, namun pada sub dimensi kompleksitas, perpustakaan tidak memiliki dukungan struktur organisasi yang baik. Selain itu, dalam sub dimensi sentralisasi perpustakaan nasional juga tidak memiliki mekanisme komunikasi dan koordinasi yang mendukung tata kelola perpustakaan yang efektif. Kemudian, dalam dimensi proses, perpustakaan nasional memiliki anggaran, SDM, dan teknologi yang mendukung kinerja perpustakaan. Namun, perpustakaan belum dapat memaksimalkan dimensi proses tersebut sebagai kekuatan organisasi (Perpusnas, 2018).

Meskipun hasil audit kelembagaan Perpusnas di atas telah menggambarkan kemampuan kelembagaan organisasi pada dimensi organisasi dan dimensi proses, namun hasil audit tersebut perlu diperkuat kembali melalui kajian budaya organisasi sehingga dapat menggambarkan dan mengidentifikasi budaya organisasi secara tepat (Ziaei, Amiri, Moghadam, \& Fayyazi, 2017). Salah satu pendekatan yang populer digunakan dalam menjelaskan budaya organisasi adalah pendekatan Competing Values Framework (CVF) yang dikembangkan oleh (Cameron \& Quinn, 2011). CVF merupakan sebuah pendekatan dan metode evaluasi nila-nilai organisasi. CVF juga merupakan sebuah strategi untuk mengenal dan memetakan karakteristik, jenis, dan kemampuan organisasi dalam mencapai kinerja yang maksimal dan dalam membentuk organisasi yang efektif, efisien, dan sukses (Currie \& Shepstone, 2013). Secara umum, CVF dapat memetakan tipe budaya organisasi pada aspek clan, adhocracy, hierarchy, dan market. Melalui penggunaan CVF, organisasi dapat dikategorikan atau digambarkan kedalam satu atau lebih dari empat jenis budaya organisasi tersebut. Kemudian, bentuk budaya organisasi dapat diklasifikasi kedalam enam dimensi organisasi yaitu karakteristik dominan organisasi, gaya kepemimpinan, manajemen sumber daya manusia, komitmen dan loyalitas, strategi, dan 
kriteria sukses organisasi (Ziaei et al., 2017).

Sejauh ini banyak studi terdahulu menggunakan pendekatan CVF untuk menjelaskan budaya organisasi perpustakaan. Shepstone \& Currie (2012) secara khusus menulis pentingnya penggunaan $\mathrm{CVF}$ dalam studi budaya organisasi perpustakaan. Salah satu tujuan penggunaan CVF dalam studi budaya organisasi perpustakaan adalah untuk memahami manajemen pengembangan sumber daya manusia, inovasi perpustakaan, strategi pencapaian visi dan misi, dan untuk memahami stabilitas organisasi perpustakaan. Chidambaranathan \& Rani (2015) melakukan kajian mendalam mengenai hubungan antara aktivitas manajemen pengetahuan dan budaya organisasi perpustakaan. Hasil penelitian mereka mengungkapkan bahwa wawasan pengetahuan manajemen tidak dipengaruhi oleh demografi profil karyawan perpustakaan tetapi dipengaruhi oleh manajemen SDM, inovasi, dan budaya strategi organisasi, sementara korelasi pengetahuan manajemen dengan dimensi hirarki organisasi perpustakaan adalah negatif. Ziaei et al (2017) juga melakukan kajian tentang budaya organisasi perpustakaan universitas di United Arab Emirates (UAE), di mana ia mengungkapkan bahwa perpustakaan universitas memiliki keunggulan pada aspek clan dan adhocracy, tetapi lemah pada aspek budaya market dan hierarchy. Dalam hal ini, Ziaei et al (2017) tata kelola perpustakaan publik dan perpustakaan akademik/universitas perlu memperhatikan tuntutan dan kebutuhan pasar sehingga keberadaan perpustakaan dapat bermanfaat positif bagi publik (customers).

Sejumlah hasil studi di atas menegaskan bahwa studi budaya organisasi sangat penting dilakukan untuk memahami profil organisasi, kondisi internal dan eksternal, dan kemampuan organisasi beradaptasi dengan perubahan yang terjadi. Namun, penelitian terdahulu belum menjelaskan secara khusus mengenai budaya perpustakaan pemerintah yang berorientasi pada peningkatan kualitas layanan perpustakaan bagi masyarakat umum di negara-negara berkembang seperti Indonesia (Cut, 2017; Pateman \& Pateman, 2017). Karena itu, kajian budaya organisasi Perpustakaan Nasional
Republik Indonesia perlu dilakukan untuk mengetahui budaya organisasi pada aspek Clan (manajemen SDM), Adhocracy (inovasi organisasi), Market (adaptasi dan strategis organisasi), dan Hierarchy (koordinasi dan struktur organisasi). Penelitian ini juga hendak menjelaskan karakteristik, jenis, dan kemampuan organisasi dalam pencapaian kinerja yang maksimal dan dalam pembentukan organisasi yang efektif, efisien, dan penentuan strategi sukses Perpusnas dalam menjalankan tugas dan fungsi sesuai amanat undang-undang tentang Perpustakaan Nasional. Kajian ini memberikan kontribusi bagi pembentukan dan pengembangan budaya organisasi perpustakaan publik yang berorientasi pada peningkatan layanan perpustakaan bagi masyarakat Indonesia.

\section{B. TINJAUAN PUSTAKA \\ 1. Kajian Budaya Perpustakaan Publik}

Perpustakaan publik merupakan perpustakaan yang dikelola oleh lembaga pemerintah dan diperuntukkan bagi publik (masyarakat), sehingga semua warga negara dapat mengakses perpustakaan publik (Schroeder, 2018). Mengingat perpustakaan publik bagian dari lembaga pemerintah, maka sistem tata kelola perpustakaan publik dipengaruhi oleh sistem dan peraturan pemerintah. Tujuan keberadaan perpustakaan publik adalah untuk mewujudkan visi pemerintah, yakni menghadirkan negara yang dapat mencerdaskan masyarakat seutuhnya (Grey \& Isaac-Menard, 2015). Karena itu, tujuan perpustakaan publik lebih luas dibandingkan tujuan perpustakaan universitas dan perpustakaan swasta.

Mengingat kebutuhan masyarakat terhadap pelayanan perpustakaan sangat beragam, maka perpustakaan publik perlu membangun budaya organisasi yang mendukung pelayanan publik yang efektif dan efisien sehingga kebutuhan masyarakat dapat terpenuhi dengan baik.

"The public library has to balance the voiced demand of a subset of the patronage with the needs of many, increasingly diverse 
groups of patrons. To accomplish this, the management style tends to be more team oriented and involves more of the library staff in order to introduce more viewpoints in the decision-making process (Sinclair, 2017).

\section{Penjelasan Sinclair (2017) di atas menggambarkan bahwa tata kelola} perpustakaan publik harus mendukung terpenuhinya kebutuhan dari banyak patron, patron dapat didefinisikan sebagai kelompok atau komunitas yang harus dilayani oleh perpustakaan publik. Untuk memenuhi kebutuhan kelompok dan komunitas, manajemen perpustakaan publik harus melibatkan stakeholders untuk mendapatkan lebih banyak gagasan dan ide dalam proses pengambilan keputusan (Chidambaranathan \& Rani, 2015). Selain itu, tata kelola perpustakaan publik perlu menekankan pada penanaman nilai komitmen dan loyalitas pegawai dalam menjalankan tugas pelayanan perpustakaan yang responsif terhadap kebutuhan komunitas. Pelayanan yang maksimal berdampak pada stabilitas perpustakaan publik sebagai institusi yang menjalankan tugas mencerdaskan dan memberdayakan masyarakat pada aspek pengetahuan dan pencerdasan.

"The glue that holds the organization together is pride in serving the local community and the dependability of jobs. Many public library staff are actually city or county employees and carry the stability and pay of a civil servant job. Promotions also may be tied into the same promotion schedule as other civil servants and provide good service with updated information (Vassilakaki \& MoniarouPapaconstantinou, 2016)".

Salah satu aspek yang perlu mendapat perhatian dari pemerintah terhadap tata kelola perpustakaan publik adalah sistem promosi jabatan pegawai perpustakaan publik, di mana promosi perlu dilakukan secara profesional yang mengikuti regulasi dan prosedur promosi jabatan pegawai sipil pada institusi pemerintah lainnya. Sejauh ini, King \& Tenopir (2013) pemerintah tidak memberikan perhatian serius terhadap pengembangan perpustakaan publik, sebaliknya pemerintah menganggap perpustakaan publik adalah tempat mutasi pegawai yang tidak produktif dari institusi lainnya. Sehingga publik menganggap bahwa pegawai perpustakaan tidak memiliki masa depan karir yang menjanjikan masa depan pegawai ke arah yang lebih baik. Padahal, keberadaan perpustakaan publik pada suatu negara sangat penting bagi pembangunan negara tersebut. Perpustakaan publik memiliki sejumlah fungsi strategis bagi pembangunan bangsa di antaranya fungsi pendidikan, penelitian, informasi, literasi, arsip, data, dan pengelolaan dokumen. Sejumlah fungsi perpustakaan tersebut menegaskan bahwa negara tidak akan berjalan dengan baik tanpa dukungan peran yang optimal dari perpustakaan. Untuk itu, pemerintah harusnya menyadari bahwa perpustakaan publik harus dikelola dengan baik melalui manajemen dan tata kelola yang mendukung terbentuknya budaya organisasi yang sehat (Aarons, Ehrhart, Farahnak, \& Hurlburt, 2015; Eisend, Evanschitzky, \& Gilliland, 2016).

Studi tentang tata kelola perpustakaan telah banyak dilakukan, baik mengulas budaya organisasi perpustakaan dengan beragam pendekatan dan obyek kajian. Vassilakaki \& Moniarou-Papaconstantinou (2016) melakukan kajian transformasi perpustakaan melalui pendekatan budaya evaluasi organisasi. Transformasi perpustakaan menggambarkan adanya perubahan tata kelola organisasi yang berupaya merespon perubahan lingkungan yang terjadi. Transformasi organisasi perlu dilakukan melalui kegiatan evaluasi kelembagaan yang difokuskan pada evaluasi perubahan kebutuhan customers terhadap produk layanan yang dibutuhkan. Karena itu, Vassilakaki \& Moniarou-Papaconstantinou mengatakan bahwa transformasi perpustakaan melalui budaya evaluasi perpustakaan adalah langkah yang esensial untuk mencapai kesuksesan organisasi bersama customers dan 
stakeholders. Dalam hal ini, perpustakaan harus menempatkan customers dan stakeholders sebagai objek sekaligus sebagai mitra organisasi.

"Transforming our libraries to reflect a culture of assessment is essential to increasing our success with customers and stakeholders and maintaining relevancy in a competi-tive environment. Creating a culture of assessment pushes the organization to focus on understanding changing customer needs and on producing value-added outcomes for customers. It encourages self-examination and openness among staff, customers, and other stakeholders. Organizational systems and structures need to be redesigned tosupport external focus and standards need to be set for all mission critical processes (Luhman \& Cunliffe, 2014)".

Penjelasan Luhman \& Cunliffe, (2014) menekankan bahwa transformasi tata kelola perpustakaan perlu disesuaikan dengan kebutuhan customers dan stakeholders. Bahkan pengelola perpustakaan perlu melibatkan mereka dalam proses transformasi organisasi perpustakaan. Salah satu yang perlu diperhatikan dalam transformasi perpustakaan adalah perubahan sistem dan struktur organisasi dilakukan untuk merespon perubahan eksternal dan standard pengelolaan perpustakaan, di mana kedua variabel ini perlu didesain dengan baik dalam bentuk satu kesatuan sistem untuk mendukung tercapainya visi organisasi. Dalam hal ini, penekanan penting dalam transformasi perpustakaan adalah mendengarkan tuntutan customers, menggunakan informasi dan data mengenai perubahan lingkungan, mengembangkan kualitas, menerapkan model pelayanan responsif. Transformasi organisasi perpustakaan tidak hanya berorientasi pada terbentuknya budaya baru namun yang jauh lebih penting adalah pengelola perpustakaan mampu menerapkan hasil transformasi organisasi kedalam kegiatan operasional perpustakaan. Struktur organisasi perpustakaan yang baru dapat diimplementasikan untuk mendukung stabilitas perpustakaan sebagai institusi pendidikan (Luhman \& Cunliffe, 2014).

"If we are to create a culture of assessment, an amalgam of committed leadership, repeated articulation of purpose and external focus, time for group learning, and thecreation of supportive organizational systems must be deliberately developed. Without this amalgam there is little chance of achieving true culture change, and there is a highprobability of becoming irrelevant and unable to communicate the value and the worth of libraries in the information society (Luhman \& Cunliffe, 2014)".

Budaya evaluasi organisasi dapat berjalan dengan baik manakala didukung oleh komitmen pemimpin organisasi. Dalam hal ini, pemimpin organisasi mampu menjalankan mengedepankan gaya kepemimpinan yang adaptif dan responsif terhadap perubahan lingkungan yang terjadi. Selain itu, dalam proses transformasi organisasi, pemimpin perlu melibatkan semua stakeholders dalam pengambilan keputusan secara deliberatif. Tanpa komitmen tersebut, transformasi perpustakaan tidak menghasilkan budaya organisasi yang tepat, ketidaksesuaian antara desain organisasi dengan kebutuhan lingkungan (customers and stakeholders), dan menciptakan kegagalan perpustakaan untuk membangun komunikasi yang baik terhadap komunitas dan masyarakat sebagai customers dari perpustakaan publik. Hasil kajian Luhman \& Cunliffe (2014) menekankan bahwa transformasi perpustakaan sangat penting dilakukan untuk merespon kebutuhan customers dan stakeholders dan untuk beradaptasi dengan perubahan lingkungan.

Currie \& Shepstone (2013) mengkaji khusus tentang hubungan antara budaya dan kinerja organisasi. Menurut Currie \& Shepstone (2013) kinerja organisasi tidak terlepas dari budaya organisasi yang ada di dalamnya. Budaya organisasi sangat berpengaruh terhadap 
kemampuan perpustakaan dalam menjalankan fungsi, kewenangan, dan tugasnya sebagai institusi pendidikan. Perpustakaan yang memiliki budaya organisasi yang baik akan mampu menciptakan organisasi perpustakaan yang sehat. Karena itu, kajian dan evaluasi budaya organisasi merupakan langkah yang harus dilakukan oleh pengelola perpustakaan dalam rangka menemukan, memahami, dan mengerti permasalahan organisasi, di mana permasalahan yang ditemukan itu dapat dijadikan sebagai input perencanaan kebijakan sehingga kebijakan yang dibuat sangat tepat untuk menyelesaikan permasalahan organisasi perpustakaan. Selain itu, kajian budaya organisasi juga dapat menghasilkan strategi penguatan kepemimpinan organisasi yang mendukung berjalannya fungsi organisasi secara efektif dan efisien.

"This research demonstrates that academic library culture can be diagnosed, understood, and changed in order to enhance organizational performance. Examining organizational culture provides evidence to guide strategy development, priority setting and planning, and the development of key leadership abilities and skills. Creating culturally appropriate support mechanisms, opportunities for learning and growth, and a clear plan of action for change and improvement are critical (Crawley-Low, 2013).

Bentuk budaya organisasi dalam suatu perpustakaan berdampak pada sistem tata kelola perpustakaan yang mendukung tersedianya nilai-nilai organisasi, kesempatan pengembangan, dan tersedianya rencana aksi untuk perubahan dan peningkatan kualitas organisasi perpustakaan. Dalam hal ini, kajian budaya organisasi berhubungan erat dengan aktivitas perencanaan, pengembangan struktur, dan formulasi rencana aksi perpustakaan. Crawley-Low (2013) secara mendalam mendiskusikan hubungan antara kajian budaya organisasi, strategi perencanaan, dan restrukturisasi perpustakaan. Dalam kajiannya itu, Crawley-Low (2013) mengatakan bahwa karyawan perpustakaan perlu terlibat secara aktif dalam pengambilan keputusan, di mana hal ini dilakukan untuk menghilangkan gap antara budaya organisasi dengan sistem tata kelola dan gaya kepemimpinan organisasi perpustakaan publik. Keterlibatan stakeholders dalam pengambilan keputusan juga dapat mendorong organisasi perpustakaan transparan dan mau menerima umpan balik dari staff perpustakaan publik.

"The study have contributed to discussions on strategic planning and organizational restructuring. Increasing the Clan culture required expanding staff participation in planning, reviewing the most significant gaps between the preferred culture and existing leadership styles, and ensuring transparency in decision-making and use of feedback (Crawley-Low, 2013).

Model kepemimpinan yang terbuka dan partisipatif pada sebuah organisasi menggambarkan bahwa organisasi tersebut memiliki clan culture yang kuat. Hal ini memungkinkan organisasi tersebut terpetakan sebagai organisasi yang memiliki tingkat kepedulian yang tinggi terhadap manajemen sumber daya manusia dan responsif terhadap tuntutan staff. Luaran dari manajemen perpustakaan yang transparan dan partisipatif adalah terbentuknya relasi dan kolaborasi internal antara unit-unit kerja perpustakaan yang mendukung terbentuknya kemampuan perpustakaan mencapai visi, misi, dan tujuan perpustakaan secara efektif dan efisien. Dalam hal ini, Crawley-Low (2013) menekankan clan culture yang baik berpengaruh pada kinerja organisasi yang maksimal.

Kemudian, kajian budaya organisasi juga berkaitan dengan kajian inovasi organisasi (adhocarcy culture) karena inovasi organisasi merupakan salah satu dimensi budaya organisasi. Inovasi organisasi berkaitan dengan subdimensi organisasi meliputi kemampuan pemimpin organisasi dalam berinovasi, baik dalam konteks pengambilan keputusan, rencana aksi, dan transformasi teknologi informasi. Inovasi organisasi merupakan salah satu 
aktivitas kepemimpinan yang paling penting untuk dilakukan guna menjaga keberlanjutan peran organisasi, termasuk organisasi publik seperti perpustakaan publik (Hurd, 2014). Sayangnya, organisasi publik dinilai minim inovasi sehingga keberadaan organisasi publik jauh tertinggal dibandingkan dengan organisasi swasta. Hal ini tidak terlepas dari pengaruh kondisi politik, budaya pemerintah, dan lingkungan sosial budaya di mana perpustakaan publik itu berada. Adhocarcy culter menekankan pada transformasi tata kelola perpustakaan dari tata kelola yang bergerak pada tataran normatif menuju tata kelola yang berorientasi pada pencapaian tujuan besar dari perpustakaan, inovasi peran kepemimpinan, dan optimalisasi alokasi sumber daya untuk kepentingan akselerasi perpustakaan (Chidambaranathan \& Rani, 2015; King \& Tenopir, 2013).

\section{Pendekatan kajian budaya organisasi perpustakaan publik}

Salah satu pendekatan yang digunakan dalam kajian budaya organisasi perpustakaan publik adalah Competing Values Framework $(C V F)$. Pendekatan ini dikembangkan oleh Cameron \& Quinn (2011) yang digunakan untuk menjelaskan dan memahami karakteristik budaya organisasi yang berpengaruh pada efektivitas dan kesuksesan organisasi. Cameron (2011) merumuskan dua dimensi utama, yakni dimensi pertama membedakan kriteria efektivitas yang menekankan pada fleksibilitas, diskresi, dinamisasi, dan control, dan dimensi kedua membedakan kriteria efektifitas yang menekankan pada orientasi internal, integrasi, kesatuan yang juga menekankan pada orientasi eksternal, yakni kompetisi organisasi (Cameron \& Quinn, 2011).

Kedua dimensi di atas tersebut tersebar pada ke empat kuadran, di mana masing-masing kuadran menunjukkan indikator efektivitas organisasi. Indikator-indikator tersebut menggambarkan pengelola/stakeholders menilai kinerja organisasi dan mendefinisikan apa yang dilihat sebagai dimensi yang baik dan relevan bagi tata kelola organisasi (Cameron \& Quinn, 2011). Kuadran kiri atas adalah nilai organisasi yang menekankan pada internal organisasi, sementara kuadran kanan bawah merupakan nilai organisasi yang menekankan pada eksternal dan fokus kontrol organisasi. Kemudian, kuadran kanan atas mendefinisikan nilai organisasi yang menekankan pada eksternal dan produktivitas organisasi sedangkan kuadran bawah kiri menekankan internal dan kontrol nilai organisasi. Menurut Cameron \& Quinn (2011) kedua dimensi dan keempat kuadran tersebut sangat tepat digunakan untuk menganalisis dan mengidentifikasi perbedaan orientasi organisasi dan nilai-nilai yang berkaitan dengan perilaku manusia di dalam sebuah organisasi. Masingmasing kuadran dilabeli sebagai Clan, Adhocarcy, Market, dan Hierarchy.

Cameron \& Quinn (2011) menguraikan definisi masing-masing tipe budaya organisasi seperti berikut ini:

1. Clan culture (internal focus and flexible) merupakan sebuah bentuk budaya organisasi yang menggambarkan adanya lingkungan organisasi sebagai tempat bersama dari semua unsur organisasi dalam menjalankan peran dan tugas masingmasing secara kolektif dan partisipatif. Dalam hal ini, pemimpin organisasi berperan sebagai mentor dan tauladan bagi semua staff organisasi. Pemimpin organisasi memberikan perhatian serius terhadap semua staff organisasi sehingga staff organisasi merasa memiliki kepastian dalam bekerja dan berkarir yang kemudian berdampak pada tingginya komitmen dan loyalitas staff terhadap organisasi. Dalam konteks ini, indikator kesuksesan organisasi dilihat dari kemampuan organisasi dalam menjalankan fungsi manajemen SDM, terutama mengenai kemampuan organisasi dalam membentuk teamwork, partisipasi, dan konsensus kolektif.

2. Adhocracy culture (external focus and flexible). Bentuk ini menekankan pada terbentuknya lingkungan organisasi sebagai tempat mengembangkan kreatifitas dan menghadapi tantangan organisasi. Dalam hal ini, pemimpin organisasi 
diposisikan sebagai inovator dan pengambil resiko. Pemimpin juga menjalankan fungsinya berdasarkan pada komitmen dan pengalaman. Kesuksesan organisasi didefinisikan dalam istilah membangun keunikan organisasi, menghasilkan produk baru, dan menjadi pemimpin inovatif dan kreatif. Standard kesuksesan lainnya adalah adanya inisiasi dan keleluasaan individu organisasi.

3. Market culture (external focus and control). Dalam hal ini, Organisasi ditekankan pada pencapaian hasil dan penyelesaian pekerjaan secara efektif. Semua unsur organisasi berkompetisi untuk mencapai tujuan organisasi, pemimpin sebagai driver, produser, dan kompetitor. Dalam konteks ini, pemimpin berperan penting untuk mencapai target dan tujuan organisasi. Fokus utama pemimpin organisasi adalah membangun reputasi dan mencapai kesuksesan organisasi. Sukses organisasi didefinsikan kemampuan organisasi membangun penetrasi pasar. Gaya kepemimpinan organisasi ditekankan pada kemampuan kompetitif menguasai pasar.

4. Hierarchy culture (internal focus and control). Struktur organisasi diformalisasikan dan distrukturisasikan secara prosedural dan birokratis. Pemimpin organisasi berperan sebagai koordinator dan pengendali organisasi sesuai ketentuan dan prosedur organisasi. Pusat perhatian pemimpin organisasi adalah menciptakan stablitas dan efisiensi organisasi. Standard kesuksesan organisasi adalah organisasi yang memiliki ketergantungan antar struktur (koordinasi), tata kelola yang terencana dan teratur, dan efisiensi biaya organisasi. Managemen SDM organisasi ditekankan pada kedisiplinan staf organisasi.

Cameron \& Quinn (2011) menggunakan instrumen assessment budaya organisasi yang disebut oleh mereka Organizational Culture Assessment Instrument (OCAI) sebagai alat mendiagnosis tipe budaya organisasi, kekuatan, dan organizational culture type, strength, and congruence yang didasarkan pada pendekatan
CVF yang dijelaskan di atas. Cameron \& Quinn (2011) merumuskan OCAI kedalam 6 (enam) subsystem budaya organisasi yang dijelaskan sebagai berikut:

1. Dominant characteristics-subsystem mengidentifikasi apakah organisasi adalah (1) tempat yang mendukung kenyamanan staff dalam menjalankan tugasnya, dan mendukung terbentuknya budaya kerjasama (teamwork); (2) kepemimpinan inovatif, kreatif, dan pengambil resiko; (3) orientasi kompetisi dan pencapaian tujuan; (4) penekanan pada kontrol dan koordinasi organisasi.

2. Leadership style - yang dapat diidentifikasikan organisasi memiliki gaya kepemimpinan (1) mentoring dan fasilitasi, (2) entrepreneur, inovatif, (3) agresif dan berorientasi hasil, (4) kepemimpinan koordinatif dan berorientasi efisiensi.

3. Management of employees mengidentifikasi organisasi yang menekankan pada (1) teamwork, konsensus, dan partisipasi, (2) kemampuan menghadapi resiko, inovasi, kebebasan, dan keunikan organisasi, (3) kompetitif dan fokus pencapaian hasil, dan (4) keamanan, adaptasi, kemampuan prediksi.

4. Perekat organisasi, di mana hal ini menjaga kesatuan dan kesolidan organisasi yang tergambarkan dari (1) loyalitas dan saling percaya, (2) komitmen untuk inovasi dan pengembangan organisasi, (3) pencapaian hasil yang maksimal, dan (4) peraturan dan kebijakan formal sebagai dasar tindakan organisasi.

5. Strategic emphasis - hal ini menekankan organisasi pada (1) pengembangan sumber daya manusia, peningkatan kepercayaan dan keterbukaan, (2) Optimalisasi sumber daya dan menciptakan tantangan baru, (3) kompetitif dan memenangkan pasar, dan (4) permanen dan stabilitas organisasi.

6. Criteria for success-bagian ini mendefinisikan kriteria kesuksesan organisasi pada (1) pengembangan sumber daya, teamwork, dan perhatian pada staff, (2) menawarkan produk dan pelayanan yang unik, (3) menguasai pasar, (4) 
ketergantungan, efisiensi, dan biaya minimum.

\section{METODE PENELITIAN}

Penelitian ini menggunakan pendekatan competing values framework (CVF) yang terdiri dari empat kuadran, yakni clan, adhocarcy, market, dan hierarchy. Pendekatan CVF didukung oleh penggunaan instrumen organizational culture assesment instrument (OCAI) yang menekankan pada penilaian enam sub sistem budaya organisasi, yaitu karakter dominan organisasi, gaya kepemimpinan, manajemen SDM, loyalitas dan solidaritas, manajemen strategis, dan kriteria sukses organisasi. Penilaian terhadap sub-sistem budaya organisasi tersebut menggunakan kuesioner, yang bertujuan untuk memahami profil budaya organisasi saat ini dan profil budaya organisasi yang dikehendaki di masa yang akan datang (masa depan).

Gambar 2 merupakan desain penelitian yang digunakan untuk menjawab pertanyaan penelitian: Bagaimana profil budaya organisasi perpustakaan nasional republik Indonesia saat ini dan bagaimana profil budaya organisasi perpustakaan nasional republik Indonesia yang dikehendaki di masa yang akan datang? Masing-masing konsep desain penelitian pada gambar 2 dijelaskan berikut ini.

\section{Pendekatan dan metode penelitian}

Penelitian ini menggunakan pendekatan Competing Values Framework (CVF) yang dikembangkan oleh Cameron \& Quinn (2011). CVF merupakan pendekatan yang digunakan untuk memahami profil budaya organisasi yang dilihat dari aspek budaya Clan, Adhocarcy, Market, dan Hierarchy. Pendekatan CVF menggunakan instrumen Organizational Culture Assessment Instrument (OCAI), di mana instrumen ini digunakan untuk memahami profil budaya melalui penggunaan 6 (enam) subsistem budaya organisasi, yaitu karakter dominan organisasi, gaya kepemimpinan, manajemen SDM, loyalitas dan solidaritas, manajemen strategis, dan kriteria sukses organisasi. Pendekatan CVF dan instrumen OCAI merupakan bagian dari jenis penelitian kuantitatif karena pendekatan dan instrumen ini menggunakan kuesioner untuk mendapatkan data score dan rata-rata serta menggunakan formula kuadran untuk memahami score dan rata-rata dari masing-masing aspek budaya organisasi.

\section{Unit penelitian dan jenis data penelitian}

Unit penelitian ini adalah Perpustakaan Nasional Republik Indonesia, UPT Perpustakaan Bung Karno di Blitar, dan UPT Perpustakaan Bung Hatta di Bukit Tinggi. Jenis data penelitian ini terdiri dari data primer dan data sekunder. Data primer adalah data yang diperoleh langsung dari stakeholders sebagai unit penelitian melalui kegiatan observasi dan kuesioner. Data sekunder merupakan data dokumen yang berkaitan dengan budaya Perpustakaan Nasional RI seperti Undangundang, tentang perpustakaan, laporan kinerja, dan evaluasi kelembagaan Perpusnas RI.

\section{Teknik pengumpulan data}

Penelitian ini menggunakan observasi dan kuesioner untuk mendapatkan data dan informasi mengenai budaya organisasi Perpusnas RI. Kuesioner disusun berdasarkan Organizational Culture Assessment Instrument (OCAI), di mana kuesioner menggambarkan 6 (enam) subsystem budaya organisasi yakni karakter dominan organisasi, gaya kepemimpinan, manajemen sumber daya manusia, solidaritas internal, manajemen strategi, dan kriteria sukses organisasi Perpusnas RI. Keenam subsitem tersebut berkaitan dengan 4 (empat) dimensi budaya organisasi yakni Clan, Adhocarcy, Hierarchy, dan Market Perpusnas RI.

\section{Organizational culture assessment instrument (OCAI)}

Organizational Culture Assessment Instrument (OCAI) adalah instrumen penilaian budaya organisasi dengan menggunakan pernyataan/pertanyaan yang berhubungan dengan enam subsistem budaya organisasi yaitu karakter dominan organisasi, gaya kepemimpinan, manajemen sumber daya manusia, solidaritas internal, manajemen 
strategis, dan kriteria sukses organisasi. Masing-masing pertanyaan yang berhubungan dengan enam subsystem budaya organisasi tersebut mengandung empat dimensi budaya organisasi yaitu Clan, Adhocarcy, Hierarchy, dan Market. Seratus poin disediakan untuk masing-masing sub-system, di mana responden membagi 100 poin tersebut kedalam empat item pernyataan.

Pembagian 100 poin pada masing-masing subsystem disesuaikan dengan pernyataan/pertanyaan dengan budaya organisasi Perpusnas RI saat ini (current culture) dan budaya organisasi Perpusnas RI yang ingin dibentuk (preferred culture). Semakin sesuai pernyataan/pertanyaan dengan current culture dan preferred culture maka semakin tinggi poin yang diberikan, sebaliknya semakin tidak sesuai pernyataan/pertanyaan dengan current culture dan preferred culture maka semakin rendah poin yang diberikan. Hasil penilaian kuesioner dihitung rata-rata score untuk keempat dimensi budaya organisasi yang diklasifikasi kedalam dua kolom, yakni kolom current culture dan kolom preferred culture. Kemudian, rata-rata skor masingmasing dimensi budaya organisasi ditempatkan pada kolom kuadran. Kuadran kiri atas merepresentasikan budaya Clan, kuadran kanan atas Adhocarcy, kuadran kanan bawah Market, dan kuadran kiri bawah Hierarchy.

\section{HASILDAN PEMBAHASAN}

\section{Budaya Organisasi Perpustakaan Nasional}

Instrumen OCAI dalam analisis budaya organisasi Perpusnas RI mencakup aspek Clan, Adhocarcy, Hierarchy, dan Market. Berdasarkan instrument tersebut maka disusun pertanyaan penilaian terhadap penerapan budaya organisasi Perpusnas RI, di mana pertanyaan tersebut meliputi karakter dominan organisasi, gaya kepemimpinan, manajemen sumber daya manusia, solidaritas internal, manajemen strategis, dan kriteria sukses organisasi. Tabel 1 merupakan jawaban dari pertanyaan yang telah disususn berdasarkan model OCAI. Kolom nomor adalah item pertanyan yang telah disusun, sedangkan kolom
A merupakan kategori budaya klan, kolom B merupakan kategori adhokrasi, kolom C merupakan kategori pasar, dan kolom D merupakan kategori hirarki.

Berdasarkan tabel 1 maka dapat dijelaskan bahwa budaya organisasi Perpusnas RI lebih dominan pada budaya hirarki (kolom D 25,547). Hal ini dapat diartikan bahwa budaya organisasi Perpusnas RI mengedepankan budaya formal dan struktural. Budaya ini menggambarkan bahwa organisasi Perpusnas RI bekerja sesuai dengan prosedur yang telah ditetapkan, pimpinan memiliki kemampuan yang baik dalam mengkoordinir dan mengorganisir serta menekankan efisiensi (Stephens \& Russell, 2004). Selain itu, budaya hirarki mengutamakan organisasi berjalan lancar, kebijakan dan peraturan formal disepakati bersama. Praktik budaya organisasi memiliki tujuan jangka panjang seperti stabilitas dan efisiensi, serta kelancaran operasional (Awan \& Mahmood, 2010).Kesuksesan praktik budaya organisasi hirarki tergantung pada penyampaian, penjadwalan, dan biaya yang rendah (CrawleyLow, 2013). Model ini juga menekankan manajemen karyawan terfokus pada kepastian ketenagakerjaan dan kemampuan prediksi (Naranjo-Valencia, Jiménez-Jiménez, \& SanzValle, 2016). Sehingga aspek yang menonjol dalam praktik budaya organisasi hirarki saat ini adalah karakter dominan, di mana karakter dominan dalam praktiknya lebih terstruktur dan terkontrol.

Tabel 2 menunjukkan hasil OCAI tentang harapan budaya organisasi Perpusnas RI di masa depan. Nilai rata-rata pada tabel 2 terletak pada kolom D, yakni budaya hirarki dengan nilai (28.834). Berdasarkan nilai tersebut maka organisasi Perpusnas RI menginginkan budaya organisasi saat ini dipertahankan dan memungkinakan untuk ditingkatkan. Kolom D pada tabel 2 dengan nilai (25.834) menunjukan bahwa perlunya peningkatan budaya hirarki organisasi di masa depan. Aspek budaya hirarki yang menonjol dari tabel 2 adalah aspek karakteristik dominan (27.647). Karakteristik dominan menunjukan bahwa Perpusnas RI merupakan organisasi yang terstruktur dan terkontrol, kedua karakterisktik tersebut 
merupakan ciri dari budaya organisasi hirarki. Tabel 1 dan 2 menunjukkan konsistensi Perpustakaan RI terhadap budaya organisasi yang diharapkan di masa depan. Meskipun demikian aspek penekanan strategis antara tabel 1 dan 2 mengalami penuruan dalam budaya organisasi Perpusnas RI, aspek tersebut terdiri dari efisiensi dan pengendalian.

\section{Analisis Profil Budaya Organisasi Perpustakaan Nasional}

Pengetahuan terhadap profil budaya organisasi membantu organisasi untuk mengidentifikasi bentuk perubahan budaya yang diharapkan serta bagaimana cara memodifikasi budaya supaya lebih memberikan manfaat bagi organisasi. Identifikasi dan penjabaran budaya organisasi menghasilkan sebuah gambaran yang komprehensif mengenai budaya organisasi, yang kemudian mempermudah implementasi perubahan budaya secara konsisten, koheren dan konsensual (Ziaei et al., 2017). Gambar 3 di bawah merupakan profil lengkap budaya organisasi Peprusnas RI saat ini dan budaya organisasi peprusnas yang diharapkan di masa depan.

a. Jenis budaya dominan

Profil budaya organisasi Perpusnas RI pada Gambar 2 menunjukan bahwa budaya organisasi Perpusnas RI adalah budaya hirarki. Profil tersebut menjelaskan bahwa secara umum lembaga-lembaga pemerintah dibentuk dengan struktur yang jelas. Pendekatan permulaan dalam organisasi modern didasarkan pada studi yang dilakukan oleh sosiolog Jerman, Max Weber, yang mempelajari organisasi pemerintahan negara-negara Eropa selama awal periode 1900. Tantangan utama organisasi periode tersebut adalah menghasilkan barang dan jasa secara efisien sebagaimana meningkatnya kompleksitas masyarakat. Untuk memenuhi tujuan tersebut Weber (1947) mengusulkan tujuh karakteristik yang dikenal sebagai atribut birokrasi klasik, meliputi: aturan, spesialisasi, meritokrasi, hirarki, pemisahan kepemilikan, impersonalitas, dan akuntabilitas. Karakteristik tersebut sangat efektif dalam mencapai tujuan organisasi dan diadopsi secara luas oleh organisasi yang menghadapi tantangan utama yaitu meningkatkan efisiensi, reliabilitas, berjalan secara baik, output yang dapat diprediksi. Studi manajemen dan praktiknya menciptakan organisasi yang hirarkis atau birokratis, praktik ini juga menciptakan stabilitas, efisiensi produk dan jasa, dan konsisten. Kesemuanya dipengaruhi oleh lingkungan yang relatif stabil sehingga mendukung aspek lain seperti kordinasi, kesamaan produk, integrasi, kontrol, dan akuntabilitas (Weber, 1947, as cited Cameron \& Quinn, 2011).

Budaya organisasi yang sesuai dengan bentuk ini ditandai dengan tempat kerja yang terstruktur dan formal. Posedur yang ada menentukan apa yang dilakukan oleh anggota organisasi. Pemimpin yang efektif dalam organisasi seperti ini adalah pemimpin yang memiliki kemampuan koordinasi dan mengorganisir yang baik. Mempertahankan organisasi agar berjalan baik merupakan hal yang penting. Perhatian jangka panjang dari organisasi adalah stabilitas, dapat diprediksi, dan efisiensi. Kebijakan dan peraturan formal dijadikan sebagai pedoman dalam organisasi (Chidambaranathan \& Regha, 2016).

Organisasi-organisasi besar dan lembaga pemerintah biasanya didominasi oleh budaya hirarki, yang dapat dilihat dari banyaknya prosedur-prosedur standar, level hirarki, serta penekanan pada penguatan peraturan. Sebagai ilustrasi, lembaga-lembaga pemerintah federal Amerika Serikat juga menunjukkan profil budaya hirarki (Cameron \& Quinn, 2011). Salah satu alasan mengapa pengetahuan tentang profil budaya organisasi menjadi penting, yaitu karena kesuksesan sebuah organisasi ditentukan oleh kesesuaian budaya organisasi dengan tuntutan lingkungan yang kompetitif (Vassilakaki \& Moniarou-Papaconstantinou, 2016).

\section{b. Kesenjangan}

Kesenjangan (gap) antara kondisi budaya organisasi saat ini dengan budaya organisasi di masa depan merupakan aspek berikutnya yang penting untuk diperhatikan, dengan mengetahui area kesenjangan terbesar antara budaya organisasi saat ini dengan budaya organisasi di masa depan maka dapat ditentukan roadmap 
perubahan yang dibutuhkan. Hasil analisis dari budaya organisasi Perpustakaan RI saat ini dan budaya organisasi di masa depan dapat diihat pada gambar 3. Gambar 3 menunjukkan tidak adanya kesenjangan yang lebar, sehingga dapat disimpulkan bahwa budaya organisasi Perpusnas RI di masa depan (setidaknya dalam kurun waktu 5-10 tahun mendatang) relatif stabil, dengan asumsi tidak ada perubahan lingkungan eksternal maupun internal yang drastis (Currie \& Shepstone, 2013).

\section{c. Kekuatan organisasi}

Tabel 2 menjelaskan bahwa aspek yang menjadi kekuatan utama dari budaya hirarki di Perpusnas RI adalah aspek karakteristik dominan yaitu lembaga Perpusnas RI merupakan organisasi yang sangat terstruktur dan terkontrol. Dengan struktur yang jelas, pembagian kerja dapat dilakuakn secara baik berdasarkan kemampuan anggota organisasi. Organisasi juga telah mendefinisikan wewenang dan tanggung jawab secara jelas, sehingga alur pekerjaan berjalan dengan lancar sesuai dengan standar operasi yang telah ditetapkan oleh organisasi. Di sisi lain, struktur tersebut menjadikan organisasi mampu membagi beban kerja secara merata kesemua bagian yang ada dalam organisasi (Cameron \& Quinn, 2011).

Aspek budaya organisasi kedua yang memiliki nilai tinggi dalam perekat organisasi yaitu kebijakan dan peraturan formal. Sebagai institusi negara, maka keberadaan Perpusnas RI sangat ditentukan oleh peraturan perundangundangan yan dibuat oleh pemerintah untuk mengatur operasional Perpusnas RI sehingga kebijakan dan peraturan yang dibuat oleh Kepala Perpusnas RI mengacu pada peraturan perundang-undangan yang lebih tinggi. Kondisi demikian menjadikan anggota Perpusnas merasa bahwa keberadaan anggota sebagai bagian dari Perpusnas RI dipersatukan oleh peraturan perundangan yang berlaku. Aspek budaya organisasi kebijakan dan perannya seperti mengkoordinir, mengorganisir serta memonitor anggota organisasi mendukung tercapainya tujuan organisasi (Cameron \& Quinn, 2011).

\section{d. Kesesuaian}

Secara keseluruhan aspek budaya organisasi Perpusnas RI (dilihat dari masingmasing profil OCAI) memiliki kesesuaian dengan profil budaya Perpusnas RI secara umum, sehingga dapat diprediksi bahwa peluang Perpusnas RI untuk dapat mencapai tujuan organisasi sangatlah besar. Cameron \& Quinn (2011) menilai bahwa kesesuaian budaya bukan suatu prasyarat dari keberhasilan suatu organisasi. Cameron \& Quinn (2011) mengungkapkan bahwa lebih banyak organisasi yang sukses dengan budaya kongruen dibandingkan dengan yang tidak. Secara rasional, kejelasan seluruh aspek organisasi dan berfokus pada nilai serta berbagi asumsi yang sama berdampak terhadap kemampuan organisasi mengeliminasi kesulitan, ketidakterhubungan, dan hambatan dalam upaya mencapai kinerja secara efektif. Untuk membangun budaya hiraki yang kuat membutuhkan ahli administrasi yang memfokuskan pada upaya mempertajam proses dan menciptakan infrastruktur yang efisien. Sedangkan untuk memperkuat budaya pasar maka membutuhkan manajer personil yang mampu menjadi rekan strategis di dalam organisasi, menyesuaikan bagian personil dengan stratei bisnis, serta menerapkan kebijakan finansial untuk aktivitas personil.

\section{e. Perbandingan dan Tren}

Salah satu cara untuk mengetahui apakah budaya organisasi telah sesuai dengan organisasi bersangkutan yakni dengan membandingkan budaya organisasi yang dimiliki dengan budaya organisasi dalam industri.

Gambar 4 menunjukkan rata-rata budaya organisasi yang diperoleh Cameron \& Quinn (2011) dari studi terhadap lebih dari 1000 organisasi. Gambar 4 tersebut juga menunjukan bahwa sebagian besar organisasi cenderung menggunakan budaya pasar dan budaya hirarki. Menurut Cameron \& Quinn (2011) lembagalembaga publik kecenderungannya menggunakan budaya hirarki, sedangkan pada industri jasa, lebih mengarah pada budaya pasar, meskipun perbedaan nilai dari kedua budaya 
tersebut tidak terlalu besar. Karena itu, budaya organisasi Perpusnas RI pada dasarnya kongruen dengan budaya organisasi pada organisasi sejenis lainnya. Sebagai institusi pemerintah, maka budaya organisasi Perpusnas RI kongruen dengan budaya organisasi lembaga publik secara umum, yaitu budaya hirarki. Sedangkan dilihat dari operasional, Perpusnas RI merupakan bagian dari industri jasa, sehingga nilai budaya pasar yang ada di Perpusnas RI memiliki skor yang relatif tinggi, hal ini juga menunjukkan adanya kemiripan dengan budaya organisasi di sektor industri jasa.

\section{E. KESIMPULAN \\ Kesimpulan}

Penelitian ini mengungkapkan bahwa profil budaya organisasi Perpusnas RI saat ini (sekarang) menggambarkan budaya hirarki, yang berorientasi pada proses, mekanisme, prosedural dan koordinatif, profesional dan rasional, pengawasan kerja, dan efesiensi organisasi. Selisih nilai budaya hirarki dengan nilai budaya market, adhocracy, dan clan tidak jauh berbeda, kendati Perpusnas RI mengedepankan budaya hirarki bukan berarti mengabaikan budaya market, adhocracy, dan clan.

\section{Saran}

Salah satu dampak negatif budaya hirarki adalah menghambat inovasi dan kreatifitas pegawai dalam menjalankan peran dan tugas yang mendukung terwujudnya visi Perpusnas RI. Karena itu, budaya hirarki perlu didukung oleh kepemimpinan, manajemen, dan loyalitas, kepedulian, serta komitmen pimpinan dan pegawai. Selain itu, perpusnas RI perlu mengimbangi dominasi budaya hirarki melalui pembentukan dan penguatan budaya market (kompetitif), adhocracy (inovatif), dan clan (kolaboratif).

\section{DAFTAR PUSTAKA}

Aarons, G. A., Ehrhart, M. G., Farahnak, L. R., \& Hurlburt, M. S. (2015). Leadership and organizational change for implementation (LOCI): A randomized mixed method pilot study of a leadership and organization development intervention for evidencebased practice implementation. Implementation Science, 10(1), 1-12. https://doi.org/10.1186/s13012-014-0192$\mathrm{y}$

Awan, M. R., \& Mahmood, K. (2010). Relationship among leadership style, organizational culture and employee commitment in university libraries. Library Management, 31(4), 253-266. https:// doi.org/10.1108/01435121011046326

Cameron, K. S., \& Quinn, R. E. (2011). Diagnosing and changing organizational culture based on the competing valuaes framework. Jossey Bass (Third edit). San Francisco: Jossey-Bass. Retrieved from https://libgen.is/book/index.php?md5=0F B4420BE416B7376D8CF5F547EDE086

Chidambaranathan, K., \& Rani, S. B. S. (2015). Knowledge management and organizational culture in higher educational libraries in Qatar: An empirical study. Library and Information Science Research, 37(4), 363-369. https://doi.org/10.1016/ j.lisr.2015.11.002

Chidambaranathan, K., \& Regha, V. S. (2016). Diagnosing the organizational culture of higher education libraries in the United Arab emirates using the competing values framework. Libres: Library \& Information Science Research Electronic Journal, 26(2), 99-112. Retrieved from https://cpbus-e1.wpmucdn.com/blogs.ntu.edu.sg/ dist/8/644/files/2017/05/LIBRESv26i2p99 -112.ChidambaranathanSakthiRegha.2016 -1zlti2e.pdf

Crawley-Low, J. (2013). The impact of leadership development on the organizational culture of a canadian academic library. Evidence Based Library and Information Practice, 8(4), 60-77. https://doi.org/10.18438/b8p593 
Currie, L., \& Shepstone, C. (2013). Mining the cultural evidence: situating planning and leadership within the academic library culture. Evidence Based Library and Information Practice, 8(4), 60-77. https://doi.org/https://doi.org/10.18438/B8 P02Q

Cut, P. Y. (2017). Peran pustakawan dalam manajemen konflik di perpustakaan. Libria, 9(2), 241-252. Retrieved from https://jurnal.ar-raniry.ac.id/index.php/ libria/article/view/2408

Eisend, M., Evanschitzky, H., \& Gilliland, D. I. (2016). The influence of organizational and national culture on new product performance. Journal of Product Innovation Management, 33(3), 260-276. https://doi.org/10.1111/jpim.12268

Grey, A., \& Isaac-Menard, R. (2015). Database Mobile Accessibility Assessment at Adelphi University Libraries. Journal of Web Librarianship, 9(2-3), 85-98. https://doi.org/10.1080/19322909.2015.10 50567

Hurd, J. M. (2014). Interdisciplinary research in the cciences: implications for library organization. College \& Research Libraries, 53(4), 283-297. https://doi.org/10.5860/crl $53 \quad 04283$

King, D. W., \& Tenopir, C. (2013). Linking information seeking patterns with purpose, use, value, and return on investment of academic library journals. Evidence Based Library and Information Practice, 8(2), 153-162. https://doi.org/10.18438/b8b02m

Luhman, J. T., \& Cunliffe, A. L. (2014). Creating a culture of assessment: A catalyst for organizational change. Portal-Libraries and the Academy, 112-117. https://doi.org/ 10.4135/9781473914643.n23

Naranjo-Valencia, J. C., Jiménez-Jiménez, D., \& Sanz-Valle, R. (2016). Studying the links between organizational culture, innovation, and performance in Spanish companies. Revista Latinoamericana de Psicologia, 48(1), 30-41. https://doi.org/10.1016/ j.rlp.2015.09.009
Pateman, J., \& Pateman, J. (2017). Managing cultural change in public libraries. Public Library Quarterly, 36(3), 213-227. https://doi.org/10.1080/01616846.2017.13 18641

Perpusnas. (2018). Hasil audit dan evaluasi kelembagaan Perpustakaan Nasional Republik Indonesia. Perpustakaan Nasional Republik Indonesia.

Schroeder, H. M. (2018). Implementing accessibility initiatives at the Michigan State University Libraries. Reference Services Review, 46(3), 399-413. https://doi.org/10.1108/RSR-04-20180043

Shepstone, C., \& Currie, L. (2012). What is organizational culture assessing organizational culture. The Research Study in Context. IEEE Antennas and Propagation Magazine, 53(5), 11-11. https://doi.org/10.1109/map.2011.6138417

Sinclair, N. T. (2017). Building a learning organization in a public library. Journal of Library Administration, 57(6), 683-700. https://doi.org/10.1080/01930826.2017.12 91183

Stephens, D., \& Russell, K. (2004). Organizational development, leadership, change, and the future of libraries. Library Trends, 53(1), 238-257. Retrieved from https://www.ideals.illinois.edu/handle/214 $2 / 1727$

Vassilakaki, E., \& Moniarou-Papaconstantinou, V. (2016). Public libraries and innovation in Greece: An option or a necessity? Advances in Library Administration and Organization, 35(April), 243-255. https://doi.org/10.1108/S0732067120160000035017

Ziaei, S., Amiri, M. R., Moghadam, H. S., \& Fayyazi, B. M. (2017). Identifying dimensions and components of competent organizational culture of public libraries in Iran. Qualitative Research, 163(2), 477-485. Retrieved from http:// www.palmajournal.org/articles/2017163/477-485.pdf 


\section{DAFTAR GAMBAR}

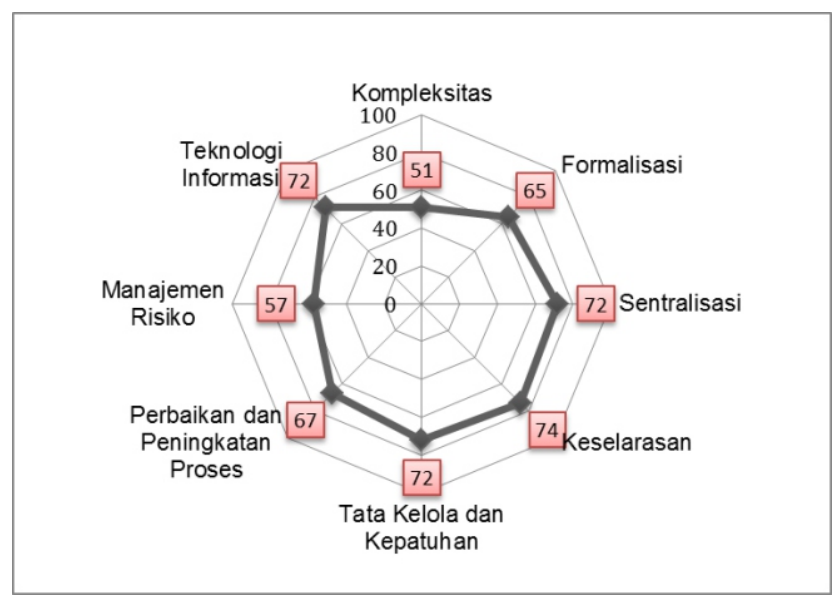

Gambar 1. Audit Kelembagaan Organisasi Perpusnas RI 2018

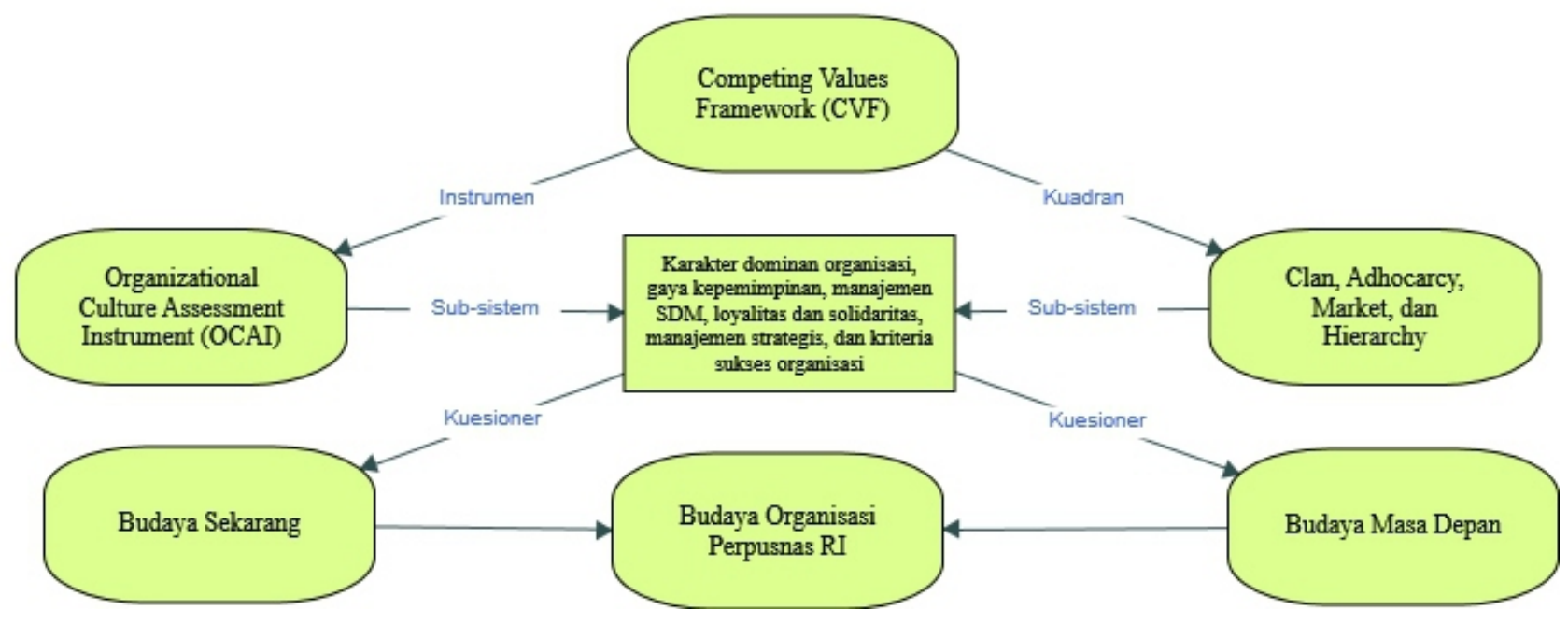

Gambar 2. Desain penelitian

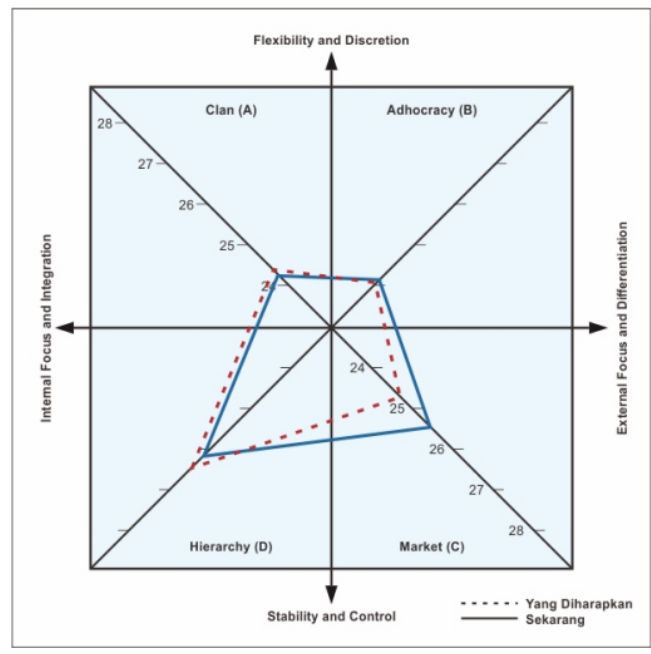

Gambar 3. Posisi budaya perpustakaan nasional dalam bingkai empat kuadran 


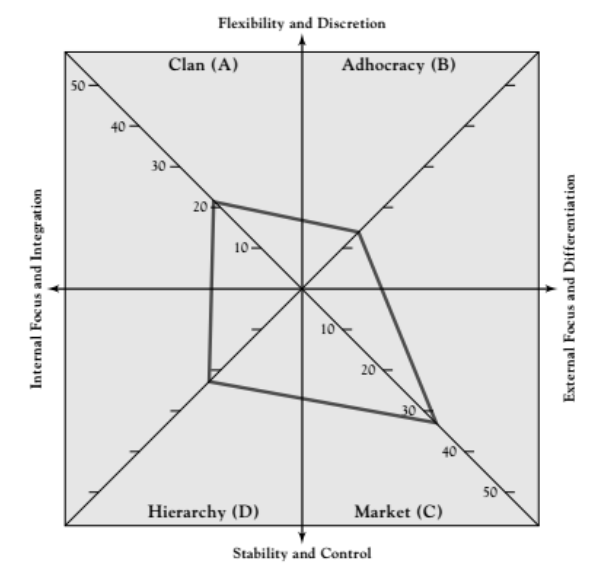

Gambar 4. Rata-rata Budaya Organisasi

\section{DAFTAR TABEL}

Tabel 1. Tabel Nilai OCAI Sekarang

\begin{tabular}{ccccc}
\hline \multirow{2}{*}{ No. } & \multicolumn{4}{c}{ Budaya } \\
\cline { 2 - 5 } & $\mathbf{A}$ & $\mathbf{B}$ & $\mathbf{C}$ & $\mathbf{D}$ \\
\hline 1 & 24.621 & 23.619 & 25.484 & 26.276 \\
2 & 24.136 & 24.554 & 25.602 & 25.708 \\
3 & 25.107 & 24.771 & 25.319 & 24.803 \\
4 & 24.581 & 24.559 & 25.108 & 25.752 \\
5 & 24.538 & 24.973 & 24.938 & 25.551 \\
6 & 24.906 & 25.044 & 24.856 & 25.194 \\
Total & 147.889 & 147.520 & 151.307 & 153.284 \\
\hline Rata-rata & $\mathbf{2 4 . 6 4 8}$ & $\mathbf{2 4 . 5 8 7}$ & $\mathbf{2 5 . 2 1 8}$ & $\mathbf{2 5 . 5 4 7}$ \\
\hline
\end{tabular}

Sumber: Data diolah dari peneltitan, 2019

Tabel 2. Nilai OCAI Harapan

\begin{tabular}{lcccc}
\hline \multirow{2}{*}{ No. } & \multicolumn{3}{c}{ Budaya } \\
\cline { 2 - 5 } & $\mathbf{A}$ & $\mathbf{B}$ & $\mathbf{C}$ & D \\
\hline 1 & 23.271 & 24.000 & 25.082 & 27.647 \\
2 & 25.097 & 24.501 & 24.621 & 25.781 \\
3 & 25.256 & 24.135 & 24.955 & 25.654 \\
4 & 24.651 & 24.598 & 25.167 & 25.584 \\
5 & 24.848 & 25.268 & 25.081 & 24.803 \\
6 & 25.121 & 24.683 & 24.664 & 25.532 \\
Total & 148.244 & 147.185 & 149.570 & 155.001 \\
\hline Rata-rata & $\mathbf{2 4 . 7 0 7}$ & $\mathbf{2 4 . 5 3 1}$ & $\mathbf{2 4 . 9 2 8}$ & $\mathbf{2 5 . 8 3 4}$ \\
\hline Sumber: Data diolah dari peneltitan, 2019 & & &
\end{tabular}

